\title{
Effects of ewe live weight and age on reproductive performance, lamb growth, and survival in Central Anatolian Merino sheep
}

\author{
A. H. Aktaş ${ }^{1}$, Ş. Dursun ${ }^{3}$, Ş. Doğan ${ }^{1}$, Z. Kiyma ${ }^{2}$, U. Demirci ${ }^{1}$, and İ. Halıci ${ }^{1}$ \\ ${ }^{1}$ Department of Animal Science, Bahri Dağdaş International Agricultural Research Institute, \\ 42020 Konya, Turkey \\ ${ }^{2}$ Department of Animal Science, Faculty of Agriculture, Eskişehir Osmangazi University, \\ 26160 Eskişehir, Turkey \\ ${ }^{3}$ Department of Clinical Sciences, Faculty of Veterinary Medicine, Aksaray University, 68000 Aksaray, Turkey \\ Correspondence to: A. H. Aktaş (ahaktas@ hotmail.com)
}

Received: 12 May 2015 - Revised: 19 November 2015 - Accepted: 26 November 2015 - Published: 10 December 2015

\begin{abstract}
The aim of this study was to evaluate the effects of premating ewe weight and age on ewe reproductive performance, lamb growth and survival in Central Anatolian Merino (CAM) sheep.

The trial included 4935 ewes and 5548 lambs from 23 breeder flocks in Eskişehir Province. The live weights (LWs) and ages of the ewes were recorded 1 week before the mating season. The number of lambs born, fertility rate, multiple birth rate (MBR), and lamb survival rate (SR) at days 75 and 120 were determined. The effects of the LW and age of the ewe were found to be important for the reproductive performance of ewes and for the lamb's growth rate $(P<0.05-0.001)$. Ewe MBRs and the birth weight $(\mathrm{BW})$ and $\mathrm{LW}$ of the lambs at days 75 and 120 increased proportionally with the increase in LW in ewes prior to mating. The fertility rate and MBR were lower $(P<0.05-0.001)$ in 1.5 -year-old ewes than in older ewes. However, lambs' SR at days 75 and 120 were not affected by the premating LW and age of the ewe. In summary, a better reproductive performance and lamb growth rate in CAM flocks may be achieved by the selection of breeding ewes from ewes weighing more than $60 \mathrm{~kg}$.
\end{abstract}

\section{Introduction}

Several factors are reported to influence reproductive performance, and the number of lambs marketed per ewe in the breeding flock is a major contributor to profitability. Sheep live weights (LWs) and age along with nutrition, weather, and season, have been reported to influence reproductive performance (Ray and Smith, 1966; Dickerson and Glimp, 1975; Gaskins et al., 2005; Akhtar et al., 2012). Increasing the premating weight and age of ewes could increase the pregnancy rate and multiple births (Molina et al., 1994; Gordon, 1997; Demirel et al., 2004; Thomson et al., 2004; Vatankhah and Salehi, 2010; Aliyari et al., 2012; Aktaş and Doğan, 2014). The effect of ewe LW was reported to be greater than the effect of premating ewe age on the ewe reproduction efficiency (Ray and Smith, 1966; Gaskins et al., 2005; Aliyari et al.,
2012; Aktaş and Doğan, 2014). Lamb survivability is also a very important subject in highly prolific sheep herds (Kott, 2014). Live weight and age of ewes were reported along with breed, sire, birth rank, and birth weight (BW) as affecting the survival rate (SR) of the lambs (Morris et al., 2000; Thomson et al., 2004; Casellas et al., 2007; Kott, 2014).

The breed, size, and age of a ewe, the birth type, lamb's sex, as well as maintenance and feeding conditions are known to have an important impact on the BW and weaning weight (WW) of lambs (Dickerson and Glimp, 1975; Gaskins et al., 2005; Notter et al., 2005; Aliyari et al., 2012; Aktaş and Doğan, 2014). An increase in the premating weights of the ewes has resulted in a proportional increase in the BW and WW of the lambs (Ray and Smith, 1966; Gaskins et al., 2005; Aliyari et al., 2012; Aktaş and Doğan, 2014). 
The main objective of this study was to determine the effect of premating LW and age of Central Anatolian Merino (CAM) ewes on their reproductive performance and on the growth characteristics and survivability of the lambs in the breeding herds.

\section{Materials and methods}

\subsection{Animals and environment}

This study included 23 Central Anatolian Merino (CAM) breeder flocks that were registered in a nationwide project called "Improvement of Central Anatolian Merino Sheep in Breeder Condition". The CAM sheep was developed in Turkey by crossing the native sheep, White Karaman (20\%), and the German Mutton Merino (80\%) breeds (GDAR, 2011). The data were collected from CAM ewes $(n=4935)$ and their lambs $(n=5548)$ during the 2012 breeding season and the 2013 lambing season. The ewes were weighed 1 week before the mating season (September-October) and grouped by their LW as $\leq 49$, 50-54, 55-59, 60-64, 65-69, and $\geq 70 \mathrm{~kg}$. A total of $197 \mathrm{rams}$ (an average of 1 ram for 25 ewes) were used in the mating season. Flock breeding was performed in all flocks, except for two flocks in which hand breeding was performed.

CAM sheep are generally raised in the Central Anatolia Region of Turkey (GDAR, 2011). The study was carried out in the Çifteler and Sivrihisar districts of Eskişehir Province in Turkey (located between $39^{\circ} 34^{\prime} \mathrm{N}$ and $31^{\circ} 17^{\prime} \mathrm{E}$; $792 \mathrm{~m}$ a.s.1.). The region is located in northwest Eskişehir, an area consisting of plains surrounded by mountains and forming the Sakarya Basin. Ranges and pastures with lowquality crops constitute $23.8 \%$ of the provincial land (Eskişehir Provincial Directorate of Food, Agriculture and Livestock, 2014). The region has cold and snowy winters and hot and arid summers. The annual rainfall was $374 \mathrm{~mm}$ in 2013 (Eskişehir Provincial Directorate of Environment and Urban Planning, 2013). In the region, housing for the sheep is usually simple and traditional with buildings made of working stone, bricks, or briquettes.

\subsection{Diets and feeding}

The registered producers were required to follow similar procedures with regard to suckling and feeding of lambs for the first 120 days of age. The producers were not allowed to fatten lambs until day 120. The ewes were fed on the pasture except in the snowy winter period, during which they were supplied with roughage (a mixture of wheat and vetch straw) and grains $\left(400 \mathrm{~g} \mathrm{day}^{-1}\right)$. After giving birth, the ewes were grazed on the pasture beginning in April and then on stubble after the grain harvest. Ewes were fed $500 \mathrm{~g} \mathrm{day}^{-1}$ of a concentrate composed of cottonseed meal and mainly barley during the last phase of the pregnancy. Amount of the con- centrate was increased to $1 \mathrm{~kg} \mathrm{day}^{-1}$ after the birth until the start of the pasture period.

After lambing, the ewes were kept with their lambs in pens containing small groups (12-15 and 5-7 ewes for singleton and twin lambing, respectively) for 2 weeks. Lambs were allowed to suckle freely and were not provided with any additional feed for the first 2 weeks. Starting from the third week of lambing, the ewes with their lambs were combined into bigger pens, and the lambs were allowed ad libitum access to alfalfa hay and lamb starter feed for 2 weeks. Lambs were separated from the ewes at 30 days of age, allowed to suckle twice a day and were fed 250-300 g concentrate feed containing mostly barley and cottonseed meal and ad libitum alfalfa and vetch hay until reaching 60 days of age. At 2 months of age, the lambs began to graze in the pastures close to the sheepfolds as separate flocks from the ewes. Suckling frequency was gradually reduced beginning at day 60, and lambs were weaned at 75 days of age. After weaning, the lambs grazed as a separate flock and were fed $250 \mathrm{~g} \mathrm{day}^{-1}$ of concentrate feed until reaching 120 days of age.

\subsection{Data collection}

The mating season was begun on 1 September and insemination was completed within 60 days in all study flocks. LWs of the ewes were determined 1 week before the start of the mating season using digital scales with a sensitivity of $100 \mathrm{~g}$. Newborn lambs were ear-tagged and traits (i.e., birth type, birth weight, and sex) observed in the study were recorded. Lamb weights were also obtained at days 75 and 120. The data were adjusted using interpolation. Then the number of lambs that survived until days 75 and 120 were used to determine survival rates for those days.

\subsection{Statistical analysis}

Binary logistic regression analysis was used to determine the influence of the LW and age of the ewes on the fertility rate, multiple birth rate (MBR), and SR of the lambs. Binary variables were coded as 1 (lambed) and 0 (did not lamb) for fertility rate and 1 (single birth) and 2 (multiple birth) for MBR. Furthermore, 1 (survived) and 0 (dead) were used for the SR of the lambs on days 75 and 120. A simple regression analysis was performed to investigate the relationship between the premating LW and the age of the ewe with the LWs of the lambs.

The effects of ewe premating LW and age, lamb sex and birth type, and the farm on the growth (BW and LWs at days 75 and 120) of the lambs were analyzed by an analysis of variance (ANOVA) using least squares means.

The mathematical model used to analyze the growth characteristics was as follows:

$Y_{i j k l}=\mu+A_{i}+B_{j}+C_{k}+D_{l}+E_{m}+e_{i j k l m}$, 
Table 1. Premating live weights $(\mathrm{kg})$ of Central Anatolian Merino ewes by age.

\begin{tabular}{lrrrrrrrr}
\hline Age at mating & 1.5 & 2.5 & 3.5 & 4.5 & 5.5 & $\geq 6.5$ & Overall & $P$ \\
\hline Number of ewes & 835 & 1013 & 1068 & 937 & 692 & 390 & 4935 & \\
LSM & $54.7^{\mathrm{c}}$ & $59.0^{\mathrm{b}}$ & $59.9^{\mathrm{ab}}$ & $59.9^{\mathrm{ab}}$ & $60.4^{\mathrm{a}}$ & $59.3^{\mathrm{ab}}$ & 58.9 & 0.001 \\
SE & 0.28 & 0.25 & 0.24 & 0.26 & 0.30 & 0.40 & 0.12 & \\
\hline
\end{tabular}

a,b,c Values with different letters differ significantly within the same row $(P<0.01)$. LSM: least squares means; SE: standard error of means.

Table 2. Reproductive performance of Central Anatolian Merino ewes and survival rates of lambs by the premating weight of ewes.

\begin{tabular}{lrrrrrrr}
\hline & \multicolumn{7}{c}{ Ewe's live weight } \\
\cline { 2 - 6 } Traits & $\leq 49$ & $50-54$ & $55-59$ & $60-64$ & $65-69$ & $\geq 70$ & Overall \\
\hline Ewes that were exposed & 684 & 941 & 1108 & 1139 & 602 & 461 & 4935 \\
Ewes that lambed & 579 & 813 & 969 & 1008 & 518 & 386 & 4273 \\
Ewes with single lambs & 507 & 640 & 721 & 650 & 299 & 181 & 2998 \\
Ewes with multiple lambs & 70 & 173 & 249 & 358 & 220 & 205 & 1275 \\
Number of lambs born & 647 & 986 & 1219 & 1366 & 739 & 591 & 5548 \\
Fertility rate ${ }^{1}, \%$ & 84.6 & 86.4 & 87.5 & 88.5 & 86.0 & 83.7 & 86.6 \\
Multiple birth rates ${ }^{2}, \%$ & 12.1 & 21.3 & 25.7 & 35.5 & 42.5 & 53.1 & 29.8 \\
Survival rate up to day 75, \% & 93.2 & 93.9 & 94.1 & 94.8 & 95.0 & 95.4 & 94.4 \\
Survival rate up to day 120,\% & 86.4 & 87.7 & 88.3 & 89.0 & 89.4 & 89.9 & 88.4 \\
\hline
\end{tabular}

${ }^{1}$ number of lambing per ewe exposed $\times 100 ;{ }^{2}$ number of multiple lambing per ewe lambing $\times 100$.

where $Y$ represents the traits and $\mu$ is the overall mean. $A_{i}$ is the ewe's LW, where $i=\leq 49,50-54,55-59,60-65,65-69$, and $\geq 70 ; B_{j}$ is the ewe's age, where $j=1.5,2.5,3.5,4.5$, 5.5 , and $\geq 6.5 ; C_{k}$ is the birth type, where $k=1$ (single) and $k=2$ (multiple); $D_{l}$ is the lamb's sex, where $l=1$ (female) and $l=2$ (male); $E_{m}$ is the farm (flock), where $m=1-23$, and $e_{i j k l m}$ was the random residual.

A Tukey test was used to calculate the significant differences between the LWs of the lambs. For statistical analysis, Minitab software was used (Minitab 16.1.1 for Windows Minitab Inc; State College PA, USA).

\section{Results}

\subsection{Premating live weights of ewes}

Premating LWs of the CAM ewes are given according to ewe age in Table 1. The LWs of 1.5-year-old ewes were lower $(P<0.01)$ than the LWs of older ewes. In another study, performed with the CAM ewes in 1969-1971, LWs of ewes were 48.7, 54.8, 58.7, 59.4, 59.6, and 59.4 at ages 1.5, 2.5, 3.5, 4.5, 5.5, and 6.5+, respectively (Yalçın et al., 1972). Both studies show that the CAM sheep reach the highest body weight at 5 years of age. The LWs in both studies were very similar at and after 3.5 years of age.

\subsection{Effect of ewe premating live weights on the reproductive performance and survival rate of the lambs}

The reproductive performance of CAM ewes and the SRs of the lambs according to the premating weight of the ewes are given in Table 2 . The odds ratios of the binary logistic regressions for the effect of ewe premating LWs on the fertility rate, MBR, and SR of the lambs are provided in Tables 3, 4, and 5 , respectively.

The fertility rate and odds ratio had a curvilinear relationship with the LW of the ewes (Tables 2 and 3). Only in ewes $\leq 49 \mathrm{~kg}$ was the odds ratio lower $(P=0.018)$ than in the ewes in the 60-64 kg group (Table 3).

The differences in the odds ratio of the LW groups in terms of the MBR were significant $(P<0.001)$. The MBR and odds ratio increased proportionally with the increase in the premating LW of ewes (Tables 2 and 4).

The effect of ewe premating LW on the survivability of lambs at days 75 and 120 was not significant. However, the SR and the odds ratio of lambs tended to increase in tandem with the increase in the ewe premating LW (Tables 2 and 5).

\subsection{Effect of the ewe's age on reproductive performance and the survival rate of lambs}

The reproductive performance of CAM ewes and the SRs of lambs according to the premating age of ewes are provided in Table 6. Furthermore, the odds ratios of the binary logistic 
Table 3. Logistic regression table for the effect of ewe premating live weight on the fertility rate.*

\begin{tabular}{lrrrrr}
\hline Predictor & Coef & SE Coef & $Z$ & $P$ & Odds ratio \\
\hline Constant & 1.7073 & 0.1061 & 16.10 & 0.001 & \\
$50-54$ & 0.1414 & 0.1425 & 0.99 & 0.321 & 1.15 \\
$55-59$ & 0.2344 & 0.1396 & 1.68 & 0.093 & 1.26 \\
$60-64$ & 0.3332 & 0.1410 & 2.36 & 0.018 & 1.40 \\
$65-69$ & 0.1118 & 0.1584 & 0.71 & 0.480 & 1.12 \\
$\geq 70$ & -0.0690 & 0.1648 & -0.42 & 0.676 & 0.93 \\
\hline * 49 LW group is the reference group. & & &
\end{tabular}

Table 4. Logistic regression model for the influence of ewe premating live weight on the multiple birth rate.*

\begin{tabular}{lrrrrr}
\hline Predictor & Coef & SE Coef & $Z$ & $P$ & Odds ratio \\
\hline Constant & -1.952 & 0.126 & -15.50 & 0.001 & \\
$50-54$ & 0.644 & 0.152 & 4.23 & 0.001 & 1.90 \\
$55-59$ & 0.885 & 0.146 & 6.06 & 0.001 & 2.42 \\
$60-64$ & 1.355 & 0.142 & 9.54 & 0.001 & 3.88 \\
$65-69$ & 1.640 & 0.154 & 10.64 & 0.001 & 5.16 \\
$\geq 70$ & 2.076 & 0.162 & 12.81 & 0.001 & 7.98 \\
\hline
\end{tabular}

$* \leq 49 \mathrm{LW}$ group is the reference group.

Table 5. Logistic regression model for the influence of ewe premating live weight on the survival rates of lambs until days 75 and 120 * $^{*}$

\begin{tabular}{lrrrrr}
\hline Predictor & Coef & SE Coef & $Z$ & $P$ & Odds ratio \\
\hline Until day 75 & & & & & \\
Constant & 2.7384 & 0.1652 & 16.57 & 0.001 & \\
50-54 & 0.0893 & 0.2174 & 0.41 & 0.681 & 1.09 \\
$55-59$ & 0.1457 & 0.2105 & 0.69 & 0.489 & 1.16 \\
$60-64$ & 0.2752 & 0.2109 & 1.30 & 0.192 & 1.32 \\
$65-69$ & 0.3796 & 0.2492 & 1.52 & 0.128 & 1.46 \\
$\geq 70$ & 0.4233 & 0.2695 & 1.57 & 0.116 & 1.53 \\
\hline Until day 120 & & & & & \\
Constant & 1.8398 & 0.1148 & 16.03 & 0.001 & \\
50-54 & 0.0929 & 0.1507 & 0.62 & 0.538 & 1.10 \\
55-59 & 0.1814 & 0.1464 & 1.24 & 0.215 & 1.20 \\
$60-64$ & 0.2225 & 0.1443 & 1.54 & 0.123 & 1.25 \\
$65-69$ & 0.2783 & 0.1671 & 1.67 & 0.096 & 1.32 \\
$\geq 70$ & 0.3111 & 0.1791 & 1.74 & 0.082 & 1.36 \\
\hline
\end{tabular}

$* \leq 49 \mathrm{LW}$ group is the reference group.

regressions for the effect of ewe premating age on the fertility rate, MBR, and SR of the lambs are given in Tables 7, 8, and 9 , respectively.

The fertility rate and odds ratio had a curvilinear relationship with the age of ewes (Tables 6 and 7). The fertility rate was affected by ewe age and the 1.5-year-old group was less fertile $(P<0.05-0.001)$ than ewes in the older groups (Table 7).

The MBRs showed a constant increase in tandem with the ewe premating LW (Table 2 and odds ratios of Table 4). The age of the ewes also affected the MBR $(P<0.001)$. The odds ratio for the MBR was lower $(P<0.009-0.001)$ in the 1.5 year-old group than the ratios in the older ewes, and the odds ratios in the 4.5- and 5.5-year-old groups were higher than the odds ratios in the other age groups (Table 7).

The effect of the ewe premating age on the SRs of the lambs at day 75 was insignificant, but it was significant at day 120. Lambs born to ewes in the 3.5- and 4.5-year-old groups had a better $(P<0.012-0.041)$ odds ratio for SRs than lambs born to ewes in the 1.5-year-old group at day 120 (Table 9). 
Table 6. Reproductive performance of Central Anatolian Merino ewes and survival rates of lambs by premating age of the ewes.

\begin{tabular}{|c|c|c|c|c|c|c|c|}
\hline \multirow[b]{2}{*}{ Traits } & \multicolumn{6}{|c|}{ Ewe age } & \multirow[b]{2}{*}{ Overall } \\
\hline & 1.5 & 2.5 & 3.5 & 4.5 & 5.5 & $\geq 6.5$ & \\
\hline Ewes that were exposed & 835 & 1013 & 1068 & 937 & 692 & 390 & 4935 \\
\hline Ewes that lambed & 679 & 882 & 948 & 831 & 598 & 335 & 4273 \\
\hline Ewes with single lamb & 533 & 625 & 647 & 551 & 404 & 238 & 2998 \\
\hline Ewes with multiple lambs & 146 & 257 & 301 & 280 & 194 & 97 & 1275 \\
\hline Number of lambs born & 825 & 1139 & 1249 & 1110 & 793 & 432 & 5548 \\
\hline Fertility rate $^{1}, \%$ & 81.3 & 87.1 & 88.8 & 88.7 & 86.4 & 85.9 & 86.6 \\
\hline Multiple birth rates ${ }^{2}, \%$ & 21.5 & 29.1 & 31.8 & 33.7 & 32.4 & 29.0 & 29.8 \\
\hline Survival rate up to 75 th day, $\%$ & 92.7 & 93.4 & 95.1 & 95.6 & 94.7 & 94.4 & 94.4 \\
\hline Survival rate up to 120 th day, $\%$ & 86.2 & 88.4 & 89.4 & 89.9 & 87.9 & 87.5 & 88.4 \\
\hline
\end{tabular}

${ }^{1}$ number of lambing per ewe exposed $\times 100 ;{ }^{2}$ number of multiple lambings per ewe that lambed $\times 100$.

Table 7. Logistic regression model for the influence of ewe premating age on the fertility rate.*

\begin{tabular}{lrrrrr}
\hline Predictor & Coef & SE Coef & $Z$ & $P$ & Odds ratio \\
\hline Constant & 1.4708 & 0.0888 & 16.57 & 0.001 & \\
2.5 & 0.4362 & 0.1290 & 3.38 & 0.001 & 1.55 \\
3.5 & 0.5961 & 0.1314 & 4.54 & 0.001 & 1.82 \\
4.5 & 0.5884 & 0.1361 & 4.32 & 0.001 & 1.80 \\
5.5 & 0.3795 & 0.1421 & 2.67 & 0.008 & 1.46 \\
$\geq 6.5$ & 0.3360 & 0.1704 & 1.97 & 0.049 & 1.40 \\
\hline
\end{tabular}

* 1.5 -year-old group is the reference group.

Table 8. Logistic regression model for the influence of ewe premating age on the multiple birth rates.*

\begin{tabular}{lrrrrr}
\hline Predictor & Coef & SE Coef & $Z$ & $P$ & Odds ratio \\
\hline Constant & -1.2949 & 0.0934 & -13.86 & 0.001 & \\
2.5 & 0.4062 & 0.1192 & 3.41 & 0.001 & 1.50 \\
3.5 & 0.5297 & 0.1166 & 4.54 & 0.001 & 1.70 \\
4.5 & 0.6180 & 0.1188 & 5.20 & 0.001 & 1.86 \\
5.5 & 0.5614 & 0.1279 & 4.39 & 0.001 & 1.75 \\
$\geq 6.5$ & 0.3974 & 0.1524 & 2.61 & 0.009 & 1.49 \\
\hline
\end{tabular}

* 1.5 -year-old group is the reference group.

\subsection{Effects of ewe premating live weight and age and lamb's birth type and sex on the growth performance of the lambs}

The effects of ewe's premating LW and age and the lamb's sex and birth type on the BW and growth performance of the lambs are shown in Table 10. Ewe premating LW had a significant effect $(P<0.001)$ on the lambs' BW and LWs at days 75 and 120. The highest BW and LWs at day 75 and day 120 were recorded in lambs born to the heaviest ewes, with $\geq 70 \mathrm{~kg}$ premating $\mathrm{LW}$, whereas the lambs born to sheep with $\leq 49 \mathrm{~kg} \mathrm{LW}$ had the lowest BW and LWs at day 75 and day 120. It is also shown that the BW and LWs of the lambs at days 75 and 120 increased proportionally with increasing ewe premating LW. Calculations showed that in response to each kilogram of increase in the LW of the ewes, the BW and LWs of the lambs at weaning and day 120 increased by 6,71 and $82 \mathrm{~g}$, respectively.

The age of ewes had an effect on the BW and LWs of lambs (Table 10). The BW of the lambs from the 1.5-yearold group was lower $(P<0.001)$ than the BW of the lambs from the 2.5- to 4.5-year-old groups. The lamb LWs at days 75 and 120 increased with maternal age. However, the LW of the lambs at days 75 and 120 differed only between groups of lambs born from the 1.5- and 4.5-year-old ewe groups $(P<0.003$, Table 10).

The BW and LWs of lamb at weaning and day 120 were affected by both lamb sex and birth type $(P<0.001)$. The weights of lambs were higher in the males than the females 
Table 9. Logistic regression model for the influence of ewe premating age on the survival rates of lambs until days 75 and 120 * $^{*}$

\begin{tabular}{lrrrrr}
\hline Predictor & Coef & SE Coef & $Z$ & $P$ & Odds ratio \\
\hline Until day 75 & & & & & \\
Constant & 2.7067 & 0.1461 & 18.53 & 0.001 & \\
2.5 & 0.3024 & 0.2038 & 1.48 & 0.138 & 1.35 \\
3.5 & 0.3197 & 0.2028 & 1.58 & 0.115 & 1.38 \\
4.5 & 0.3794 & 0.2099 & 1.81 & .071 & 1.46 \\
5.5 & 0.2038 & 0.2169 & 0.94 & 0.348 & 1.23 \\
$\geq 6.5$ & 0.1051 & 0.2525 & 0.42 & 0.677 & 1.11 \\
\hline Until day 120 & & & & & \\
Constant & 1.8243 & 0.1023 & 17.83 & 0.001 & \\
2.5 & 0.1744 & 0.1381 & 1.26 & 0.207 & 1.19 \\
3.5 & 0.2850 & 0.1397 & 2.04 & 0.041 & 1.33 \\
4.5 & 0.3645 & 0.1448 & 2.52 & 0.012 & 1.44 \\
5.5 & 0.1464 & 0.1490 & 0.98 & 0.326 & 1.16 \\
$\geq 6.5$ & 0.0885 & 0.1749 & 0.51 & 0.613 & 1.09 \\
\hline
\end{tabular}

* 1.5 -year-old group is the reference group.

Table 10. The effects of ewe premating live weight and age, lamb's sex, and birth type on the birth weight and growth performance of the lambs.*

\begin{tabular}{|c|c|c|c|c|c|c|}
\hline \multirow[b]{2}{*}{ Traits } & \multicolumn{2}{|c|}{ Birth weight } & \multicolumn{2}{|r|}{ Day 75} & \multicolumn{2}{|c|}{ Day 120} \\
\hline & $n$ & $\mathrm{LSM} \pm \mathrm{SE}$ & $n$ & $\mathrm{LSM} \pm \mathrm{SE}$ & $n$ & $\mathrm{LSM} \pm \mathrm{SE}$ \\
\hline \multicolumn{7}{|c|}{ Ewe premating LW } \\
\hline$\leq 49$ & 647 & $4.13 \pm 0.029^{d}$ & 603 & $16.6 \pm 0.18^{d}$ & 559 & $25.8 \pm 0.25^{\mathrm{d}}$ \\
\hline $50-54$ & 986 & $4.22 \pm 0.024^{\mathrm{d}}$ & 926 & $17.6 \pm 0.15^{\mathrm{c}}$ & 864 & $27.2 \pm 0.21^{\mathrm{c}}$ \\
\hline $55-59$ & 1219 & $4.33 \pm 0.021^{\mathrm{c}}$ & 1147 & $18.5 \pm 0.13^{b}$ & 1076 & $28.3 \pm 0.19^{b}$ \\
\hline $60-64$ & 1366 & $4.40 \pm 0.020^{\mathrm{c}}$ & 1295 & $18.9 \pm 0.13^{\mathrm{b}}$ & 1215 & $28.6 \pm 0.18^{b}$ \\
\hline $65-69$ & 739 & $4.52 \pm 0.027^{\mathrm{b}}$ & 702 & $19.6 \pm 0.17^{\mathrm{a}}$ & 661 & $29.7 \pm 0.24^{\mathrm{a}}$ \\
\hline$\geq 70$ & 591 & $4.66 \pm 0.031^{\mathrm{a}}$ & 564 & $20.2 \pm 0.19^{\mathrm{a}}$ & 531 & $30.1 \pm 0.27^{\mathrm{a}}$ \\
\hline$P$ & & 0.001 & & 0.001 & & 0.001 \\
\hline \multicolumn{7}{|c|}{ Ewe premating age } \\
\hline 1.5 & 825 & $4.24 \pm 0.026^{\mathrm{b}}$ & 765 & $18.3 \pm 0.16^{\mathrm{b}}$ & 711 & $27.7 \pm 0.23^{b}$ \\
\hline 2.5 & 1139 & $4.40 \pm 0.022^{\mathrm{a}}$ & 1064 & $18.5 \pm 0.14^{\mathrm{ab}}$ & 1007 & $28.3 \pm 0.19^{\mathrm{ab}}$ \\
\hline 3.5 & 1249 & $4.41 \pm 0.021^{\mathrm{a}}$ & 1188 & $18.8 \pm 0.13^{\mathrm{ab}}$ & 1116 & $28.5 \pm 0.19^{\mathrm{ab}}$ \\
\hline 4.5 & 1110 & $4.47 \pm 0.022^{\mathrm{a}}$ & 1061 & $19.0 \pm 0.14^{\mathrm{a}}$ & 998 & $28.7 \pm 0.20^{\mathrm{a}}$ \\
\hline 5.5 & 793 & $4.38 \pm 0.025^{\mathrm{ab}}$ & 751 & $18.5 \pm 0.16^{\mathrm{ab}}$ & 697 & $28.4 \pm 0.23^{\mathrm{ab}}$ \\
\hline$\geq 6.5$ & 432 & $4.36 \pm 0.034^{\mathrm{ab}}$ & 408 & $18.4 \pm 0.21^{\mathrm{ab}}$ & 378 & $28.1 \pm 0.30^{\mathrm{ab}}$ \\
\hline$P$ & & 0.001 & & 0.003 & & 0.003 \\
\hline \multicolumn{7}{|c|}{ Lamb's sex } \\
\hline Female & 2765 & $4.26 \pm 0.015^{\mathrm{b}}$ & 2608 & $17.9 \pm 0.09^{\mathrm{b}}$ & 2442 & $26.9 \pm 0.13^{b}$ \\
\hline Male & 2783 & $4.50 \pm 0.015^{\mathrm{a}}$ & 2629 & $19.3 \pm 0.09^{\mathrm{a}}$ & 2465 & $29.7 \pm 0.13^{\mathrm{a}}$ \\
\hline$P$ & & 0.001 & & 0.001 & & 0.001 \\
\hline \multicolumn{7}{|c|}{ Lamb's birth type } \\
\hline Single & 2998 & $4.79 \pm 0.015^{\mathrm{a}}$ & 2884 & $20.5 \pm 0.09^{\mathrm{a}}$ & 2682 & $30.7 \pm 0.12^{\mathrm{a}}$ \\
\hline Multiple & 2550 & $3.97 \pm 0.017^{\mathrm{b}}$ & 2353 & $16.7 \pm 0.10^{\mathrm{b}}$ & 2225 & $25.9 \pm 0.14^{\mathrm{b}}$ \\
\hline$P$ & & 0.001 & & 0.001 & & 0.001 \\
\hline Overall & 5548 & $4.38 \pm 0.011$ & 5237 & $18.6 \pm 0.07$ & 4907 & $28.3 \pm 0.10$ \\
\hline
\end{tabular}

LSM: least squares means; SE: standard error of means. ${ }^{\text {a,b,c,d }}$ Values with different letters differ significantly within the same column $(P<0.01)$. ${ }^{*}$ The effect of farm is not shown in Table 10 . 
and in the singletons than the multiples in all periods (Table 10).

\section{Discussion}

\subsection{Fertility rate and multiple birth rate}

In present study, the fertility rate and odds ratio had a curvilinear relationship with the ewe premating LW (Tables 2 and $3)$. However, there was a significant difference only between two weight groups ( $\leq 49$ and $60-64$, Table 3 ). The MBR and odds ratio for the MBR increased proportionately to the ewe premating LW, and the heaviest ewes (i.e., $\geq 70 \mathrm{~kg}$ ) had the highest MBR (53.1\%). The current findings are similar to those of McLaughlin (1970), Molina et al. (1994), Gordon (1997), and Vatankhah and Salehi (2010) that offspring number and sheep efficiency were affected by the increase in the ewe LW. Similarly, MBR was found to increase proportionately to LW increases in the Afshari ewes: the heaviest $(74-80 \mathrm{~kg}$ ) group had the highest MBR (Aliyari et al., 2012). In another study, the twinning rate was reported to increase with the LW of the ewe in Awassi sheep, where the highest rate of twin births was at $51-55 \mathrm{~kg}$ (Thomson and Bahhady, 1988). Heavier ewes achieved puberty in the first breeding season, had a higher number of lambs, and produced more multiples at 2 years old (Edwards et al., 2014). Kenyon et al. (2014) reported a greater effect of ewe LW on reproductive performance in younger ewes than older ewes. All these data indicate that well-developed ewes may have an advanced reproductive performance compared to weaker ewes at the same age.

In this study, the fertility rate and MBR had a curvilinear increase with the age of the ewe. The 1.5-year-old group had a lower fertility rate and MBR than the older ewes (Tables 6, 7 and 8). Similar outcomes where the fertility rate and MBR of 2-year-old ewes were lower than in the older ewes have been reported (Demirel et al., 2004; Thomson et al., 2004; Aliyari et al., 2012; Aktaş and Doğan, 2014). Dickerson and Glimp (1975) reported that the number of lambs born per 100 ewes showed a curvilinear increased with the age of the ewe from 100 at 1 year to 160 at 6 years and back to 135 for 9-year-old ewes. However, according to the findings of McLaughlin (1970), the age of the Merino ewe had no effect on reproductive performance.

\subsection{Survival rates of lambs}

In the current study, the effects of the ewe LW on SRs of the lambs at day $75(93.2-95.4 \%$, Table 2) and day 120 (86.4$89.9 \%$, Table 2) were insignificant (Table 5), but the SRs tended to increase with increasing ewe LW (Tables 2 and 5). Concerning the effects of dam age on lamb survivability, similar results were reported by Yalçın et al. (1972) in the CAM sheep raised on a state farm in Central Anatolia. However, in that study, relatively higher lamb survival rates in all age groups and different periods could be attributed to better conditions at the state farm compared to producer conditions. Aktaş and Doğan (2014) have reported that the SR was higher in lambs born to the heaviest ewes when compared to the SR of lams from lightest ewes in White Karaman sheep.

In this study, ewe age affected the SRs of the lambs at day $120(86.2-89.9 \%$, Tables 6 and 9) but not at day 75 (92.7-95.6\%, Tables 6 and 9). In CAM sheep, the highest lamb survivability was achieved in lambs from 3.5- and 4.5-year-old ewes at days 120. According to the findings of Sawalha et al. (2007), the hazard rate was lower for the lambs of intermediate-age ewes compared to those of younger or older ewes in the first 2 weeks postpartum. However, in these lambs the SRs of were not affected by the age of the ewe during the periods of 15-120 and 121-180 days. Two other studies reported that the SR until the weaning of lambs born to 2-year-old ewes was lower than in those born to older ewes (Demirel et al., 2004; Thomson et al., 2004). In spite of a smaller litter size, a consistently high mortality rates was reported for lambs born to 2-year-old ewes (Morris et al., 2000). In that study, the SR was higher in lambs of 3and 4-year-old ewes and lower in lambs of 2- and 5-year-old ewes. Knight et al. (1988) also reported a quadratic effect of ewe age on lamb survival that increased in concert with increasing ewe age up to 5 years and then declined rapidly for 6-year-old ewes. Lower SRs for lambs from the youngest ewes could be explained by weaker prenatal nutrition due to young ewes being smaller and/or still developing in addition to providing poorer postnatal maternal care that may lead to hypothermia (Berger, 1997).

The variation in terms of the SR in lambs between this study and other studies may stem from differences in the fertility rate and MBR of the different breeds, feed sources and quite likely maintenance, and climatic conditions.

\subsection{Live weights of lambs}

In the current study, LWs of the lambs at birth and at days 75 and 120 increased in proportion to the increase in LWs of the ewes. The highest LWs were observed in the lambs born to the heaviest ewes (Table 10). Similarly, the increase in the WWs of the lambs was related to increasing dam weights by Ray and Smith (1966), Yalçın et al. (1972), Gaskins et al. (2005), Aliyari et al. (2012), and Aktaş and Doğan (2014).

In the current study, when the LWs of lambs born to the heaviest and the lightest ewes were compared, the heaviest group produced lambs that weighed 11.4, 17.8, and $14.3 \%$ more in terms of BW and LWs at days 75 and 120, respectively. In addition, a $1 \mathrm{~kg}$ increase in the maternal LW was found to result in 6,71, and $82 \mathrm{~g}$ increases in lamb BW and LWs at days 75 and 120 day, respectively. The increases in the growth rate of lambs were higher than those reported by Ray and Smith (1966). In the current study, the lambs had an average BW equal to $7.44 \%$ of the LW of the ewes, 
which had an average weight of $58.9 \mathrm{~kg}$. Similar values $(6.5-$ $10.6 \%$ ) were reported by Donald and Russell (1970) for ewes with $\mathrm{LW}$ of $100 \mathrm{~kg}$. When the lamb BWs were categorized by ewe weight, lambs had 8.4, 8.1, 7.6, 7.1, 6.7, and $6.6 \%$ of the LW of the ewes weighing $\leq 49,52,57,62,67$, and $\geq 70 \mathrm{~kg}$, respectively. These findings confirm the theory that BWs of a litter as a proportion of ewe weight decrease, while maternal weights increase. As shown in this study along with other studies (Ray and Smith, 1966; Aliyari et al., 2012), the highest LW produced lambs with the highest BW. Most likely, the reason for this phenomenon is the body fat degradation serving as a source for more milk production in the heavy ewes. In addition to this, most lighter ewes may be first-time lambing, young ewes with a lack of experience, which might result in poorer maternal care compared to mature ewes (Corner et al., 2013).

In the present study, the BW of lambs born to ewes in the 1.5-year-old group was lower than the BWs of lambs born to ewes of the 2.5-, 3.5-, and 4.5-year-old group. Furthermore, LWs of these lambs at days 75 and 120 were significantly lower than those of the lambs born to 4.5-year-old ewes (Table 10). Similarly, the BW and WWs of lambs born to 2-yearold ewes were lower than those of lambs born to older ewes (Saghi et al., 2007; Koncagül et al., 2013). In another study, the age of the ewe did not affect the weight of lambs at birth, but the 2- and 7-year-old ewes tended to wean lighter lambs (Ray and Smith, 1966). However, some researchers could not find any significant differences between the ewe age groups in terms of birth and weaning weights (Cemal et al., 2005; Aliyari et al., 2012; Aktaş and Doğan, 2014). Less-developed mammary glands and, therefore, insufficient milk production for their lambs may be the reason for lighter lambs from 2year-old ewes.

In agreement with several studies (Saghi et al., 2007; Ozder et al., 2009; Koncagül et al., 2013; Aktaş and Doğan, 2014), a lamb's sex and birth type had an important impact on the lamb's BW and LWs at weaning and day 120 (Table 10), with an advantage of male and singletons over female and twin lambs.

In conclusion, the MBR, BW, and LWs of the lambs at weaning and day 120 were affected by the premating LW and age of the CAM ewes, and these features improved proportionally with increasing ewe LW. Consequently in most instances, the heavier ewes can be expected to produce heavier lambs at weaning and at day 120 in the CAM breed. The age of ewes alone or in combination with the LW should also be taken into account whenever possible since reproductive performance of the ewes and growth performance of their lambs were low in first-time lambing ewes compared to older ewes. Therefore, a better reproductive performance and high profitability may be achieved by increasing the premating weight of ewes through improved feeding strategies. This is especially important in first-time lambing ewes that are raised under poor nutritional conditions. In summary, a better reproductive performance and lamb growth rate in CAM sheep may be achieved by selecting breeding ewes that have a better nutritional status and attain higher LW at puberty and, therefore, in the following years.

Acknowledgements. This study was supported by the General Directorate of Agricultural Research and Policy in Turkey, through the project called "Improvement of Central Anatolian Merino sheep under breeder conditions in Eskişehir Province" (TAGEMHAYSÜD-06/08/01/01). This is one of the many projects under the main project called "National Genetic Improvement Project for Small Ruminants at Breeders' Conditions".

Edited by: S. Maak

\section{References}

Akhtar, M., Javed, K., Abdullah, M., Ahmad, N., and Elzo, M. A.: Environmental factors affecting preweaning growth traits of Buchi sheep in Pakistan, J. Anim. Plant. Sci., 22, 529-536, 2012.

Aktaş, A. H. and Doğan, Ş.: Effect of live weight and age of Akkaraman ewes at mating on multiple birth rate, growth traits, and survival rate of lambs, Turk. J. Vet. Anim. Sci., 38, 176-182, 2014.

Aliyari, D., Moeini, M. M., Shahir, M. H., and Sirjani, M. A.: Effect of BSC, live weight and age on reproductive performance of Afshari Ewes, Asian J. Anim. Vet. Adv., 7, 904-909, 2012.

Berger, Y. M.: Lamb mortality and causes-A nine-year summary at the Spooner Agricultural Research Station, in: Proceedings of the 45th Annual Spooner Sheep Day, University of WisconsinMadison, USA, 23 August 1997, 33-40, 1997.

Casellas, J., Caja, G., Such, X., and Piedrafita, J.: Survival analysis from birth to slaughter of Ripollesa lambs under semi-intensive management, J. Anim. Sci., 85, 512-517, 2007.

Cemal, İ., Karaca, O., and Altın, T.: Live weights of Kıvırcık ewes and lambs in some periods under extensive management conditions, Turk. J. Vet. Anim. Sci., 29, 1329-1335, 2005.

Corner, R. A., Mulvaney, F. J., Morris, S. T., West, D. M., Morel, P. C. H., and Kenyon, P. R.: A comparison of the reproductive performance of ewe lambs and mature ewes, Small Rumin. Res., 114, 126-133, 2013.

Demirel, M., Kurbal, O. F., Aygun, T., Erdogan, S., Bakici, Y., Y1lmaz, A., and Ulker, H.: Effects of different feeding levels during mating period on the reproductive performance of Norduz ewes and growth and survival rate of their lambs, J. Biol. Sci., 4, 283287, 2004.

Dickerson, G. E. and Glimp, H. A.: Breed and age effects on lamb production of ewes, J. Anim. Sci., 40, 397-408, 1975.

Donald, H. P. and Russell, W. S.: The relationship between live weight of ewe at mating and weight of new born lamb, Anim. Prod., 12, 273-280, 1970.

Edwards, S. J., Juengel, J. L., O'Connell, A. R., Johnstone, P. D., Farquhar, P. A., and Davis, G. H.: Attainment of puberty by ewes in the first year of life is associated with improved reproductive performance at 2 years of age, Small Rumin. Res., 123, 118-123, 2014.

Eskişehir Provincial Directorate of Environment and Urban Planning: Eskişehir Province 2013 environmental status report, available at: http://www.csb.gov.tr/db/ced/editordosya/ 
Eskisehir_icdr2013.pdf (last access: 4 October 2015), 2013 (in Turkish).

Eskişehir Provincial Directorate of Food, Agriculture and Livestock: 2014 work report, available at: http://eskisehir.tarim.gov. tr/Menu/2/Faaliyetlerimiz (last access: 3 October 2015), 2014 (in Turkish).

Gaskins, C. T., Snowder, G. D., Westman, M. K., and Evans, M.: Influence of body weight, age and weight gain on fertility and prolificacy in four breeds of ewe lambs, J. Anim. Sci., 83, 16801689, 2005.

GDAR (General Directorate of Agricultural Research and Policy): Central Anatolian Merino, in: Domestic Animal Genetic Resources in Turkey, Ankara, Turkey, 68-69, 2011.

Gordon, I.: Controlled Reproduction in Sheep and Goats, CABI Publishing, Wallingford, UK, 272 pp., 1997.

Kenyon, P. R., Thompson, A. N., and Morris, S. T.: Breeding ewe lambs successfully to improve lifetime performance, Small Rumin. Res., 118, 2-15, 2014

Knight, T. W., Lynch, P. R., Hall, D. R. H., and Hockey, H. U. P.: Identification of factors contributing to the improved lamb survival in Marshall Romney sheep, New Zeal. J. Agr. Res., 31, 259-271, 1988.

Koncagül, S., Vural, M. E., Karataş, A., Akça, N., and Bingöl, M.: Reproductive performance of ewes and growth characteristics of lambs in Zom Sheep reared in Karacadağ District, Kafkas Univ. Vet. Fak. Derg., 19, 63-68, 2013.

Kott, R.: Montana farm flock sheep production handbook, available at: http://animalrangeextension.montana.edu/sheep/ reproduction.html (last access: 1 February 2015), 2014.

McLaughlin, J. W.: Relations between body weight at mating, age and the subsequent reproductive performance of Merino and Corriedale ewes, Proc. Aust. Soc. Anim. Prod., 8, 366-370, 1970.

Minitab: Minitab 16.1.1 for Windows, Minitab Inc, State College, PA, USA, 2010.
Molina, A., Gallego, L., Torres, A., and Vergara, H.: Effect of mating season and level of body reserves on fertility and prolificacy of Manchega ewes, Small Rumin. Res., 14, 209-217, 1994.

Morris, C. A., Hickey, S. M., and Clarke, J. N.: Genetic and environmental factors affecting lamb survival at birth and through to weaning, New Zeal. J. Agr. Res., 43, 515-524, 2000.

Notter, D. R., Borg, R. C., and Kuehn, L. A.: Adjustment of lamb birth and weaning weights for continuous effects of ewe age, Anim. Sci., 80, 241-248, 2005.

Ozder, M., Sezenler, T., Onal, A. R., and Ceyhan, A.: Genetic and non-genetic parameter estimates for growth traits in Turkish Merino lambs, J. Anim. Vet. Adv., 8, 1729-1734, 2009.

Ray, E. E. and Smith, S. L.: Effect of body weight of ewes on subsequent lamb production, J. Anim. Sci., 25, 1172-1175, 1966.

Saghi, D. A., Khadivi, H., Navidzadeh, M., and Nikbakhti, M.: Study on influence of environmental effect on birth weight, weaning weight and daily growth of Baluchi sheep, Pak. J. Nutr., 6, 436-437, 2007.

Sawalha, R .M., Conington, J., Brotherstone, S., and Villanueva, B.: Analyses of lamb survival of Scottish Blackface sheep, Animal, 1, 151-157, 2007.

Thomson, B. C., Muir, P. D., and Smith, N. B.: Litter size, lamb survival, birth and twelve week weight in lambs born to crossbred ewes, Proceedings of NZGA, 66, 233-237, 2004.

Thomson, E. F. and Bahhady, F. A.: A note on the effect of live weight at mating on fertility of Awassi ewes in semiarid northwest Syria, Anim. Prod., 47, 505-508, 1988.

Vatankhah, M. and Salehi, S. A.: Genetic and non-genetic factors affecting Lori-Bakhtiari ewe body weight and its relationship with productivity, Small Rumin. Res., 94, 98-102, 2010.

Yalçın, B. C., Müftüioğlu, .Ş, and Yurtçu, B.: Possibility of improving important production characteristics of Konya Merino sheep through selection I. Performance levels for different characteristics, Vet. J. Ankara Univ., 19, 227-255, 1972. 